\title{
TESTOVANIE STABILITY OBRAZU NA ÚČELY MERANÍ POSUNOV METÓDOU FOTOGRAMETRICKEJ ČASOVEJ ZÁKLADNICE
}

\author{
IMAGE STABILITY TESTING FOR DISPLACEMENT MEASUREMENTS \\ USING TIME BASE PHOTOGRAMMETRY
}

\author{
Andrej Hideghéty ${ }^{*}, 1$ \\ *andrej.hideghety@stuba.sk \\ ${ }^{1}$ Stavebná fakulta, Slovenská technická univerzita v Bratislave, Radlinského 11, 81005 Bratislava, Slovensko
}

\begin{abstract}
Abstrakt
Fotogrametrické metódy sa čoraz viac využívajú pri meraní posunov a pretvorení. Jednou z fotogrametrických metód je časová základnica, ktorá sa využíva hlavne na meranie zmien v obrazovej rovine. Jedna z najdôležitejších podmienok na dosiahnutie vysokej presnosti merania touto metódou je zabezpečenie stability kamery v zmysle nemenných prvkov vonkajšej orientácie (PVO). V tejto práci sú skúmané primárne náklony kamery využitím sklonomeru Leica Nivel, ich vplyv a možnosti analytickej korekcie. V tejto súvislosti bol vykonaný experiment snímaním testovacieho a kalibračného bodového pol’a kamerou Sony Alpha A7R III, pričom na podložku kamery bol pripevnený aj spomínaný sklonomer. Na spracovanie meraní bol využitý fotogrametrický softvér Photomodeler.
\end{abstract}

Kl'účové slova

Fotogrametria, posuny, pretvorenia, časová základnica

\begin{abstract}
Photogrammetric methods are increasingly being used to measure displacements and deformations. One of the photogrammetric methods is the time base, which is mainly used to measure changes in the image plane. One of the most important conditions for achieving high accuracy with this method is to ensure the stability of the camera external orientation parameters (EOP). In this work primarily tilts of the camera using the Leica Nivel inclinometer, their impact and the possibilities of analytical correction are investigated. In this context, an experiment was performed by capturing the test and calibration point field with a Sony Alpha A7R III camera, while the inclinometer was also attached to the camera base. Photomodeler photogrammetric software was used to process the measurements.
\end{abstract}

\section{Key words}

Photogrammetry, deformations, displacements, time base photogrammetry

\section{1 ÚVOD}

Meranie posunov a pretvorení mostných a iných objektov je kritickým faktorom pre zaistenie ich spol'ahlivosti. Už pri výstavbe, resp. počas zat’ažovacích skúšok mostov je nevyhnutné prípadné deformácie častí objektu odhalit', aby sa predišlo výraznému zhoršeniu konštrukcie. Merania na tieto účely sa vykonávajú spravidla geometrickou niveláciou, ale aj inými geodetickými metódami, vrátane fotogrametrie. V súčasnosti z fotogrametrických metód metóda časovej základnice [1] má stále väčší potenciál v tejto oblasti. Princíp fotogrametrickej časovej základnice spočíva v snímkovaní objektov v rôznych časových rezoch. Vd’aka vývoju kamier, snímačov, objektívov a fotogrametrických spracovatel'ských systémov táto metóda nachádza čím väčšie uplatnenie $\mathrm{v}$ meraní zmien v snímkovej rovine, a tým pádom aj v meraní posunov a pretvorení. Táto metóda vyžaduje niekol’ko predpokladov pre dosiahnutie vysokej presnosti, ktoré sú nasledovné [2]:

- zabezpečenie nemenných PVO kamery,

- rovnobežnost' snímkovej roviny s rovinou alebo smerom predpokladaných posunov, 
- meranie obrazových súradníc pozorovaných bodov s presnost'ou vyššou ako 0,1 pixela,

- $\quad$ správne určenie mierky,

- vysoké priestorové a geometrické rozlíšenie,

- eliminácia vplyvu distorzií objektívu.

Z horeuvedených predpokladov práve zabezpečenie stability kamery v zmysle nemenných PVO je najnáročnejšie. Existujú však dva prístupy ktorými sa dá čiastočne korigovat' prípadné zmeny PVO, a to hardvérovo a analyticky. Hardvérová stabilizácia v tomto prípade predstavuje usadenie kamery na pilier, resp. t’ažký fotogrametrický statív (nad $7 \mathrm{~kg}$ ), dostatočnú aklimatizáciu prístrojového vybavenia a elimináciu vonkajších vplyvov v čo najväčšej miere. Tieto vplyvy môžu byt' napr. vibrácie a svetelné a tepelné žiarenia, kvôli ktorým môže dôjst' ku krúteniu statívu. V tejto práci bude testovaný špecifický prístup hardvérovej stabilizácie, jeho overenie Nivelom a zváženie analytickej stabilizácie. Testy boli vykonané v laboratórnych podmienkach.

\section{SÚČASNÝ STAV PROBLEMATIKY}

Najdôležitejším úkonom je zabezpečenie fixnej pozície kamery v zmysle nemenných PVO. Už malé uhlové zmeny osi záberu kamery môžu spôsobit' relatívne vel'ké zmeny v obrazových súradniciach, a môžu skreslit' posuny merané metódou časovej základnice [1]. Yoneyama a Ueada korigovali zmeny PVO pri snímkovaní mosta na základe fixných oblastí na snímke a výsledky porovnali deformetrami, ktorými sa dobre zhodovali [3]. Jiang a Jauregui využili vlícovacie body pre analytickú stabilizáciu kamery [4]. Počas experimentálneho merania Bosporského mosta Wagner, Avşar a ich kolektív využili pilier pre stabilizáciu, o analytických korekciách však nepísali [5], [6], [7]. Abolhasannejad et al. na snímke vybrali oblasti kde sa predpokladalo že nedôjde k posunom, a na základe týchto oblastí stabilizovali kameru analyticky [8]. Fraštia počas laboratórneho testu zaznamenal, že sklápanie zrkadla kamery môže spôsobit’ otrasy, ale to v rámci presnosti merania kruhových kódových značiek [9].

\section{METODIKA}

Experiment bol vykonaný kamerou Sony Alpha A7R III a sklonomerom Leica Nivel 210/220. Technické špecifikácie kamery sú uvedené v Tab. 1.

Tab. 1 Technické špecifikácie použitej kamery a snímky.

\begin{tabular}{cc}
\hline \multicolumn{2}{c}{ Sony Alpha A7R III } \\
\hline Typ kamery & Mirrorless (Bezzrkadlovka) \\
Typ snímača & Full frame CMOS \\
Rozlíšenie snímača & $42,4 \mathrm{Mpx}$ \\
Vel'kost' pixela & $4,48 \mu \mathrm{m}$ \\
Vel'kost' snímača & $35,6 \times 23,8 \mathrm{~mm}$ \\
Objektív & Sony FE $35 \mathrm{~mm} \mathrm{f} / 1,8$ \\
ISO & 100 \\
Clona & 5 \\
Expozičný čas & $1 / 30$ sek. \\
Obrazový formát & RAW s konv. na TIFF \\
\hline
\end{tabular}

Táto bezzrkadlová digitálna kamera bola zvolená preto, aby sa predišlo otrasom zapríčineným sklápaním zrkadla počas experimentu. Sklonomer Leica Nivel umožňuje vysoko presné meranie stability meracieho systému s výsledkami v reálnom čase. Tento dvojosí senzor má rozlíšenie $0,001 \mathrm{mrad}$.

Experimentálne meranie bolo vykonané usadením kamery a sklonomeru na spoločnú podložku, a usadením tejto podložky na t'ažký statív. Táto konfigurácia bola umiestnená 3,7 m od kalibračného pol’a a tým pádom vel'kost' strany pixela po priemete na objekt (GSD - ground sample distance) bola 0,47 mm. Po aklimatizácii prístrojov sa spustilo hodinové intervalové snímkovanie, pričom sa vyhotovila každú minútu jedna snímka. Sklonomer meral s krokom niekol'ko sekúnd. Nakol'ko TKBP sa nachádza v suteréne Stavebnej fakulty Slovenskej technickej univerzity $\mathrm{v}$ Bratislave, svetelné aj tepelné podmienky boli konštantné a v laboratóriu sa nikto nepohyboval ani nenachádzal, čím sa predišlo prípadným otrasom a vibráciám. 
Snímky boli spracované v softvéri Photomodeler. RAD kódové značky na TKBP boli merané fotogrametricky metódou Least-Square Matching (LSM). Na každej snímke bolo nájdených 96 terčov. Kvôli vel'kému počtu bodov a etáp bolo potrebné vyvinút' algoritmus v programovacom softvéri MATLAB pre hromadné spracovanie. Tento algoritmus postupne porovnával jednotlivé etapy s nultou etapou a následne posuny graficky znázornil.

\section{VÝSLEDKY}

Pri grafickom znázornení posunov sa preukázala systematická zložka. Trend smerom doprava bol prítomný pre všetky etapy. Smer a vel'kost' posunov je graficky znázornená na Obr. 1.

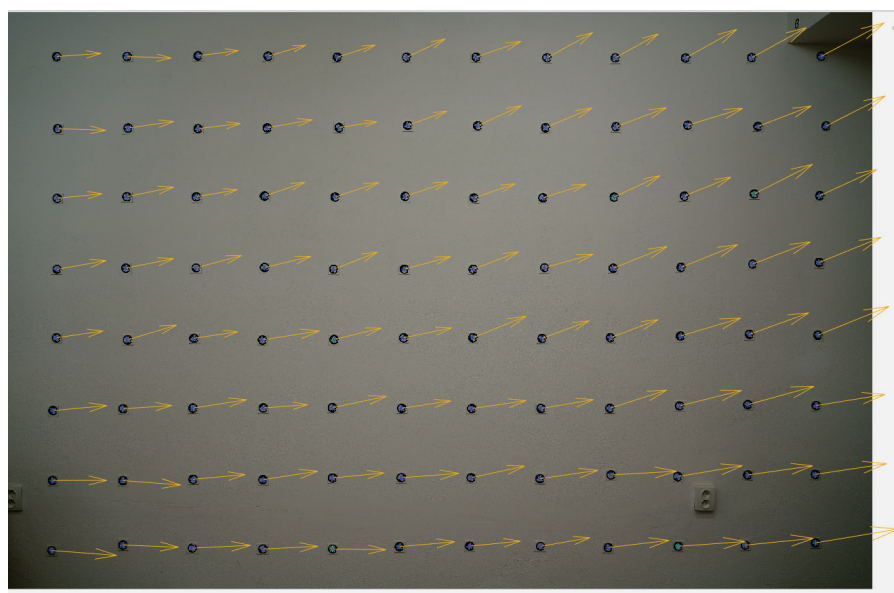

Obr. 1 Smer a vel'kost' posunov.

Kvôli pozorovanému trendu boli priemerné posuny v osiach x a y znázornené v grafoch (Obr. 2), ako aj merania zo sklonomeru (Obr. 3).

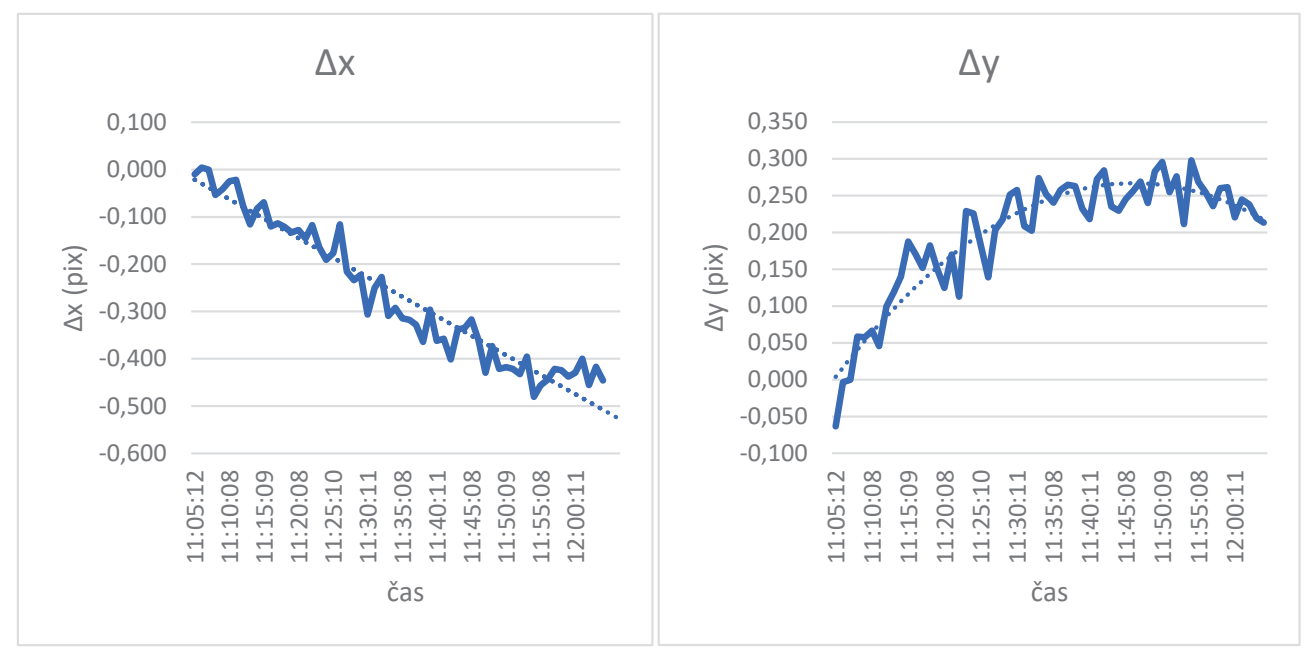

Obr. 2 Zmeny obrazových súradníc v osiach x a y obrazového súradnicového systému ich aproximácia trendovou spojnicou. 


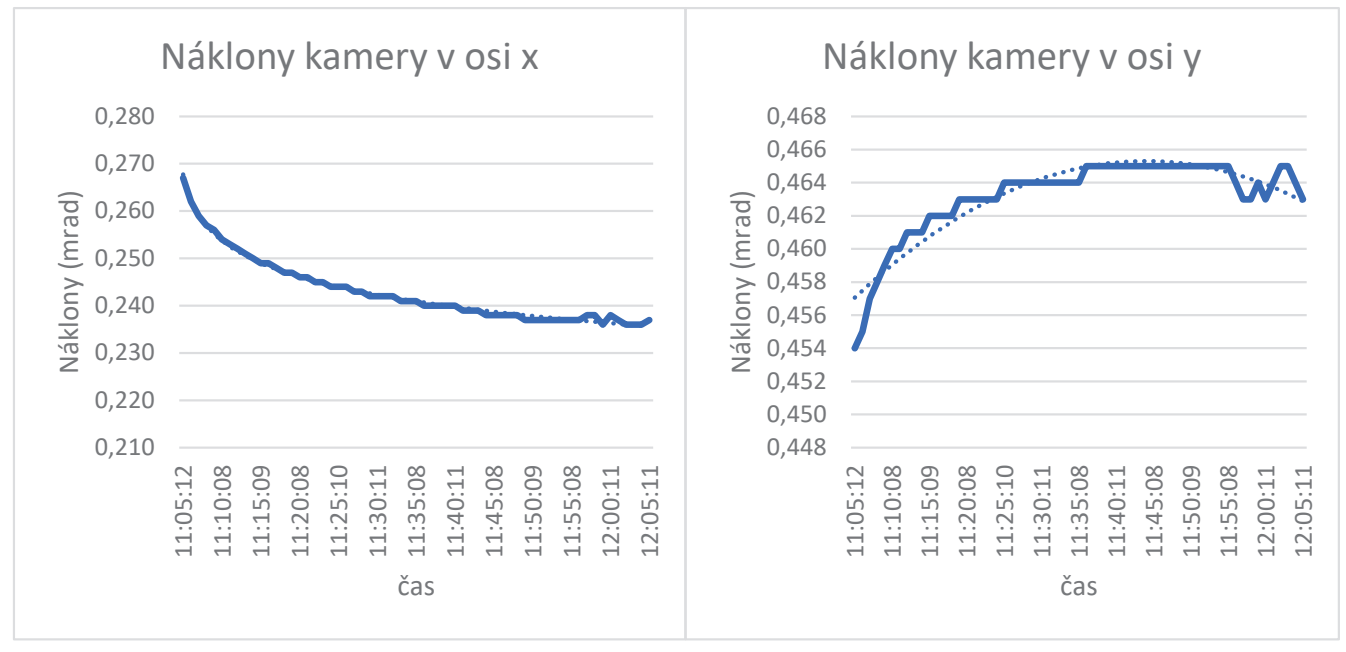

Obr. 3 Náklony kamery v osiach x a y v súradnicovom systéme sklonomeru a ich aproximácia trendovou spojnicou.

\section{DISKUSIA}

Na stránke výrobcu sa nachádza interpretácia súradnicového systému kamery, ktorú je nevyhnutné uviest' pre správnu interpretáciu výsledkov (Obr. 4).

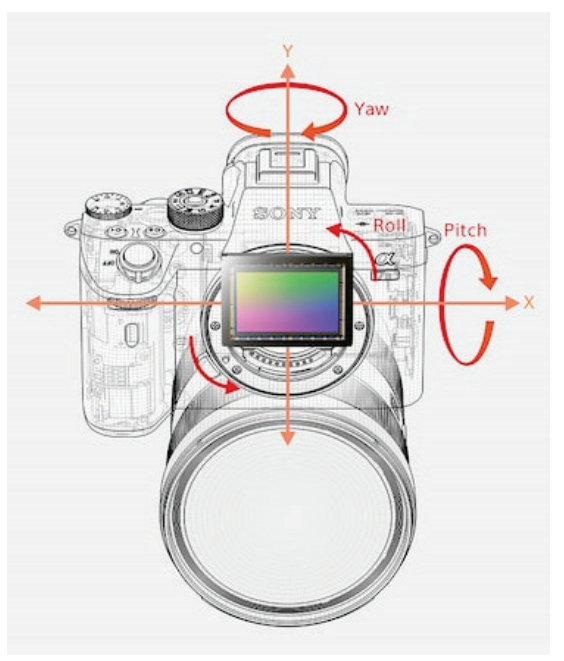

Obr. 4 Výrobcom udaný súradnicový systém kamery [10].

Podl'a grafov posuny v smere osi y v obrazovom súradnicovom systéme silno korelujú náklonmi kamery v osi y podl'a sklonomeru. Toto prakticky znamená, že kamera sa naklonila okolo svojej osi x (pitch). Trendy v obidvoch grafoch boli aproximované polynómom druhého stupňa. Náklony $\alpha$ boli prepočítané na zmeny $\mathrm{v}$ pixeloch $\Delta \mathrm{y}$ na základe vzt’ahu (1).

$$
\Delta \mathrm{y}=\frac{f * \tan (\alpha)}{p i x},
$$


Kde f je ohnisková vzdialenost', pix vel'kost' strany pixela na snímači.

Následne zmeny v osi y boli korigované podl’a náklonov. Korigované zmeny v obrazových súradniciach v osi y sú znázornené na Obr. 5.

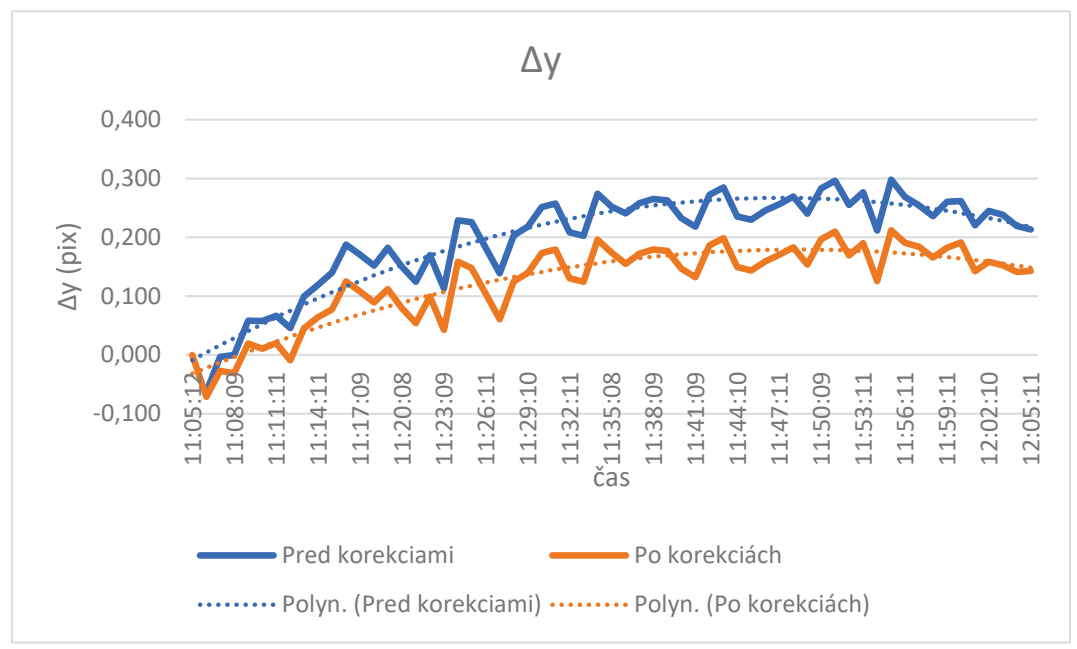

Obr. 5 Zmeny v osi y pred korekciám a po korekciách.

Z grafu vyplýva, že síce zmeny v osi y sú menšie ako pred korekciami, okrem samotných náklonov zmeny spôsobia aj iné neodhalené vplyvy.

Zmeny v x-ovej osi, ktoré sú v súradnicovom systéme označené ako roll, nie je možné korelovat's náklonmi nameranými sklonomerom. Trend posunov v smere osi x v obrazovom súradnicovom systéme skôr poukazuje na posun, resp. naklonenie celej sústavy doprava.

\section{ZÁVER}

Tento príspevok riešil možnost' overenia stability obrazu na účely merania metódou fotogrametrickej časovej základnice. Konfigurácia pozostávala z kamery, sklonomeru, spoločnej podložky a statívu. V rámci experimentu bolo nasnímkované TKBP $\mathrm{v}$ intervale jednej hodiny každú minútu raz. Posuny v obrazovej rovine namerané fotogrametricky, a náklony kamery merané sklonomerom preukázali silnú koreláciu v trende, ale po korekciách tieto nežiadané posuny boli len čiastočne odstránené. Zmeny súradníc v osi x nepreukázali koreláciu s náklonmi nameranými sklonomerom, a naznačujú posun celej sústavy v osi x kamery doprava. Tieto problémy s kamerovou konfiguráciu preukazujú na dôležitost' stabilnej podložky, napr. pilieru v d'alších experimentoch, nakol'ko problémy vyplývali pravdepodobne práve z nedostatočnej stability statívu. Ciel’om d'alšieho výskumu bude zopakovat' experiment usadením kamery na pilier, a vykonat' snímkovanie v priebehu niekol'kých hodín.

\section{Pod'akovanie}

Tento príspevok bol vypracovaný s podporou Ministerstva školstva, vedy, výskumu a športu Slovenskej Republiky v rámci Agentúry na podporu výskumu a vývoja, č. projektu APVV-18-0472 a Vedeckej grantovej agentúry, č. projektu VEGA 1/0584/19.

\section{Použité zdroje}

[1] FRAŠTIA, M. a kol.: Možnosti metódy časovej základnice v digitálnej fotogrametrii. In Geodézia, kartografia a geografické informačné systémy 2016 [elektronický zdroj]: zborník článkov z 9. vedecko-odbornej konferencie, Demänovská dolina, SR, 21 - 23. 9. 2016 Geodesy, Cartography and Geographic Information Systems 2016. 1. vyd. Košice : Technická univerzita v Košiciach, 2016, CDROM, [10] s. ISBN 978-80-553-2603-0

[2] FRAŠTIA, M. Vybrané aplikácie fotogrametrie v oblasti merania posunov. Habilitačná práca. 
[3] YONEYAMA, Satoru; UEDA, Hiroki. Bridge deflection measurement using digital image correlation with camera movement correction. Materials transactions, 2012, 53.2: 285-290.

[4] JIANG, Ruinian; JAUREGUI, David V. Development of a digital close-range photogrammetric bridge deflection measurement system. Measurement, 2010, 43.10: 1431- 1438.

[5] WAGNER, Andreas, et al. Bridge monitoring by means of video-tacheometer-a case study. avnAllgemeine Vermessungs-Nachrichten, 2013, 120.8-9: 283-292.

[6] WAGNER ${ }^{1}$, Andreas, et al. Monitoring Concepts Using Image Assisted Total Stations. 2016.

[7] AVŞAR, Özgür; AKÇA, Mehmet Devrim; ALTAN, Orhan. Photogrammetric deformation monitoring of the second Bosphorus Bridge in Istanbul.

[8] ABOLHASANNEJAD, Vahid; HUANG, Xiaoming; NAMAZI, Nader. Developing an optical imagebased method for bridge deformation measurement considering camera motion. Sensors, 2018, 18.9: 2754.

[9] FRAŠTIA, M. Vybrané aplikácie fotogrametrie v oblasti merania posunov. Habilitačná práca. 2017.

[10] https://electronics.sony.com/imaging/interchangeable-lens-cameras/all-interchangeable-lenscameras/p/ilce7rm3-b 